\title{
The effect of voting rights on firm value
}

\section{Cristina Mabel Scherrer $^{1}$ | Marcelo Fernandes ${ }^{2}$}

\author{
${ }^{1}$ Norwich Business School, University of East \\ Anglia, Norwich, UK and CREATES \\ ${ }^{2}$ Sao Paulo School of Economics, FGV, Sao \\ Paulo, Brazil

\section{Correspondence} \\ Cristina Mabel Scherrer, Norwich Business \\ School, University of East Anglia, Norwich \\ Research Park, Norwich NR4 7TJ, UK. \\ Email: c.scherrer@uea.ac.uk
}

\begin{abstract}
We present a simple framework for dual-class stock shares in which common shareholders receive public and private cash flows (i.e., dividends and any private benefit of holding voting rights) and preferred shareholders only receive public cash flows. We isolate these two cash flows in order to identify the role of voting rights on equity-holders' wealth. In particular, using a structural cointegrated VAR model, we find a negative relationship between the value of the voting right and the preferred shareholders' wealth.
\end{abstract}

\section{KEYWORDS}

dual-class shares, private benefits, voting right

\author{
JEL CLASSIFICATION \\ G15; G32; G34; G38
}

\section{1 | INTRODUCTION}

The value of voting rights may have similar magnitude to the value of dividend rights, especially in markets that offer low protection to minority shareholders (Zingales, 1994). In fact, minority shareholders might get only a small fraction of the verifiable income due to scarce legal protection, but a much larger share of the unverifiable income (i.e., private benefits of control) because competition for control protects the value of voting rights (Grossman \& Hart, 1988).

Deviations from the one-share-one-vote rule presumably indicate poorer corporate governance practices because they induce shareholders to act in self-interest (Burkart \& Lee, 2008). This leads to a negative impact on both firm value (Gompers, Ishii, \& Metrick, 2003) and operating performance (Klapper \& Love, 2004). See also Adams and Ferreira (2008) for a review.

This is an open access article under the terms of the Creative Commons Attribution-NonCommercial-NoDerivs License, which permits use and distribution in any medium, provided the original work is properly cited, the use is non-commercial and no modifications or adaptations are made.

(c) 2020 The Authors. International Review of Finance published by John Wiley \& Sons Australia, Ltd on behalf of International Review of Finance Ltd (2020) 
This article aims to assess the impact of voting rights on firm value. As common shares have voting rights, their prices reflect both verifiable and unverifiable cash flows. In contrast, preferred share prices mirror only verifiable cash flows (Dyck \& Zingales, 2004). We exploit this difference to disentangle the effects of verifiable and unverifiable cash flows on firm value. In particular, we identify the voting premium and dividend innovations using a structural cointegrated vector autoregressive (CVAR) model to isolate the response to a shock in the firm's ability to generate public and private cash flows. The structural nature of the methodology is crucial for a reduced-form approach cannot uncover the underlying relationship between firm value and voting right, as pointed out by Himmelberg, Hubbard, and Palia (1999) and Coles, Lemmon, and Meschke (2012), among others.

Empirically, we focus on stock data from Brazil, where preferred shares are widespread for historical reasons (Fernandes \& Novaes, 2019). We not only find strong support to the desirability of the one-share-one-vote rule, but also corroborate previous evidence of a negative relation between firm value and voting rights (Gompers, Ishii, \& Metrick, 2009).

\section{VOTING RIGHTS AND CASH FLOWS}

Consider a firm with two classes of shares. Common shares have both cash-flow and voting rights, whereas preferred shares only have cash-flow rights. Both share prices depend on the fundamental value of the firm given by the present value of the expected verifiable cash flows. The latter impounds any news that investors perceive as changes in expected inflows or outflows of cash to and fro the company. The price of common shares also reveals the present value of any expected private (unverifiable) cash flow that voting rights might generate. The ability to generate private cash flows depends obviously on corporate governance regulation, which may offer more or less protection to minority shareholders.

We define the fundamental price $m_{t}$ as the present value of the expected stream of dividend payments to preferred shareholders:

$$
m_{t}=\mathbb{E}_{t}\left[\sum_{i=0}^{\infty} D_{p, t+i} /(1+r)^{i}\right],
$$

where $\mathbb{E}_{t}$ denotes the conditional expectation given that the information set at time $t, D_{p, t+i}$ is the dividend payment to the preferred shareholders at time $t+i$, and $r$ is the appropriate discount rate.

We define the common-preferred premium $d_{t}$ as the difference in cash flows rights of common and preferred shareholders:

$$
d_{t}=\underbrace{\mathbb{E}_{t}\left[\sum_{i=0}^{\infty} D_{c, t+i} /(1+r)^{i}\right]+\mathbb{E}_{t}\left[\sum_{i=0}^{\infty} v_{t+i} /(1+r)^{i}\right]}_{\text {common share holders' cash flows }}-\underbrace{\mathbb{E}_{t}\left[\sum_{i=0}^{\infty} D_{p, t+i} /(1+r)^{i}\right]}_{\text {preferred share holders'cash flows }},
$$

where $D_{c, t+i}$ denotes the dividend payments to common shareholders, $v_{t+i}$ is the present value of the voting right at time $t+i$ and $\mathbb{E}_{t}\left[\sum_{i=0}^{\infty} v_{t+i} /(1+r)^{i}\right]$ is the expected present value of the private cash flows that voting rights may generate.

Zingales (1995) and Doidge (2004) point out that, as long as there is competition on the interest for control, the common-preferred premium depends on the expected present value of private benefits. Accordingly, we assume that any common shareholder enjoys private cash flows. Note that dividend payments $D_{c, t+i}$ and $D_{p, t+i}$ are public cash flows, with $D_{c, t+i} \leq D_{p, t+i}$ given that preferred shareholders receive at least as much dividends as common shareholders. The common-preferred premium $d_{t}$ depends on two components: the difference in dividend payments $\left(\mathbb{E}_{t}\left[\sum_{i=0}^{\infty} D_{c, t+i} /(1+r)^{i}\right]-\mathbb{E}_{t}\left[\sum_{i=0}^{\infty} D_{p, t+i} /(1+r)^{i}\right]\right)$ and the present value of the voting right $\left(\mathbb{E}_{t}\left[\sum_{i=0}^{\infty} v_{t+i} /(1+r)^{i}\right]\right)$. 
Our first goal is to provide a framework that allows us to disentangle the effect of the voting right value from the fundamental price of the firm. Because our identification and estimation strategies rely on a time-series framework, it is natural to model the fundamental prices in Equations (1) and (2) as random walk processes,

$$
\begin{aligned}
& m_{t}=m_{t-1}+\eta_{t}^{m}+\pi \eta_{t}^{v} \\
& d_{t}=d_{t-1}+\eta_{t}^{v}+\kappa \eta_{t}^{m},
\end{aligned}
$$

where $\eta_{t}^{m}$ and $\eta_{t}^{v}$ are the innovation terms associated with the share price and voting right, respectively.

For identification purposes within a structural CVAR context, we must augment our price system to also consider prices in a foreign market (Gonzalo \& Ng, 2001; Yan \& Zivot, 2010). As the prices in the foreign market are traded in a foreign currency, we also include the efficient exchange rate as an additional latent price

$$
e_{t}=e_{t-1}+\eta_{t}^{e}
$$

where $\eta_{t}^{e}$ is the innovation term associated with the exchange rate. The innovations $\eta_{t}^{e}, \eta_{t}^{m}$, and $\eta_{t}^{v}$ are assumed to be contemporaneously uncorrelated.

From Equation (3), the innovation in the voting right value can have a direct effect on the firm's fundamental price. The value of $\pi$ gauges the effect of changes in the value of voting rights on the cash flow, whereas $\kappa$ gives the impact of the efficient price on the common-preferred premium. Estimation and identification of $\kappa$ and $\pi$ require a cointegrated system of at least four observed prices that reflect the latent efficient prices in Equations (3)-(5). To this end, we make use of the logarithms of the observed preferred and common share prices in the home market ( $p_{t}^{p}$ and $p_{t}^{c}$, respectively), of the preferred share price $p_{t}^{f}$ in the foreign market, and of the exchange rate $w_{t}$ :

$$
\begin{gathered}
w_{t}=e_{t}+b_{w} \eta_{t}^{T}, \\
p_{t}^{p}=m_{t}+b_{p} \eta_{t}^{T} \\
p_{t}^{c}=m_{t}+d_{t}+b_{c} \eta_{t}^{T}, \\
p_{t}^{f}=m_{t}+e_{t}+b_{p, f} \eta_{t}^{T},
\end{gathered}
$$

where the error $\eta_{t}^{T}$ stems from transitory trading frictions. Note that $p_{t}^{c}$ and $p_{t}^{p}$ are functions of the latent fundamental price $m_{t}$ exclusively, whereas $p_{t}^{f}$ also depends on the exchange rate.

We estimate the cumulative impulse response function that gives the total effect of shocks in $\eta_{t}^{v}$ and $\eta_{t}^{m}$ to the observed prices. Specifically, we define the structural infinite vector moving average (VMA $(\infty))$, which is a function of uncorrelated innovations,

$$
\Delta Y_{t}=\phi_{0} \eta_{t}+\phi_{1} \eta_{t-1}+\phi_{2} \eta_{t-2}+\cdots=\sum_{i=0}^{\infty} \phi_{i} \eta_{t-i}
$$

where $Y_{t}=\left(w_{t}, p_{t}^{p}, p_{t}^{c}, p_{t}^{f}\right)^{\prime}, \eta_{t}=\left(\eta_{t}^{e}, \eta_{t}^{m}, \eta_{t}^{v}, \eta_{t}^{T}\right)^{\prime}$, and $\phi_{i}, i=1,2,3, \ldots$ are $4 \times 4$ parameter matrices. The total response of the observed prices to a shock on $\eta_{t}$ is given by $\Phi=\sum_{i=0}^{\infty} \phi_{i}$, which depend exclusively on the structural parameters $\pi$ and $\kappa^{11}$ : 


$$
\text { total responses }=\Phi\left(\begin{array}{c}
\eta_{t}^{e} \\
\eta_{t}^{m} \\
\eta_{t}^{v} \\
\eta_{t}^{T}
\end{array}\right)=\left(\begin{array}{ccc} 
& \cdots \\
\vdots & 1 & \pi \\
(\kappa+1) & (\pi+1) & \vdots \\
& \cdots
\end{array}\right)\left(\begin{array}{c}
\eta_{t}^{e} \\
\eta_{t}^{m} \\
\eta_{t}^{v} \\
\eta_{t}^{T}
\end{array}\right) .
$$

The parameter $\pi$ summarizes the impact of $\eta_{t}^{v}$ on the preferred share prices. It represents the effect on the fundamental price from an innovation in the voting right value. Finally, the term $1+\kappa$ gives the total response on common shares after shocks to the fundamental share price. As a result, the structural impulse response functions enable us to identify and make inference on the structural parameters in Equations (3) and (4).

\section{EFFECTS OF VOTING RIGHTS ON FIRM VALUE}

Investors observe distinct cash flows from common and preferred shares. Divergence between the voting right and the cash flow right can reflect a possible premium over the preferred share, in mergers and acquisitions (see Zingales, 1994, 1995; Dyck \& Zingales, 2004). This cost put in place to retain control likely depends on country-level institutional factors, which can vary substantially across countries (Khanna \& Yafeh, 2007). For example, Dyck and Zingales (2004) document that some country-specific factors affect the voting premium, whereas Gompers et al. (2003) and Klapper and Love (2004) show that equity holders' rights may vary across firms within the same country.

Bearing that in mind, we perform a country-specific study, just as many papers in the literature (Bigelli and Croci (2013) focus on the Italian case). The Brazilian stock market is particularly interesting for this study, because of the prevalence of dual-class shares. ${ }^{22}$ Brazilian firms may have up to $50 \%$ of the total number of shares issued as preferred shares, ${ }^{33}$ so that trading activity is significant for both share classes.

As for the foreign market, we consider American Depositary Receipts (ADRs). There are 25 Brazilian firms trading in the US, of which 14 have both common and preferred shares traded on the Brazilian stock exchange: Ambev (beverage), Bradesco (finance), Santander (finance), Braskem (petrochemical), Electrobras (energy), Copel (energy), CBD (food distribution), Cemig (energy), Itau Unibanco (finance), Oi (telecommunication), Petrobras (oil), Telefonica (telecommunication), Tim (telecommunication), and Vale (mining). We use daily prices from January 2007 to December 2014.

Cointegration tests reveal one cointegrating vector for the majority of the companies. This results in three common factors, namely, the fundamental exchange rate, the fundamental share price and the common-preferred premium. We then estimate a vector error correction model to obtain matrix $\Phi .^{44}$

Table 1 displays the results. The $\kappa$ estimates are significantly negative for every firm. Positive news about the firm's cash flows lead to a higher dividend payment for both share classes and a possible reduction in the common-preferred premium. From Equation (11), $\pi$ gives the percentage impact on the fundamental price of the firm (which affects both common and preferred shares) as a result of a shock on the voting value. For instance, the first row documents that there is a $-0.96 \%$ effect on the fundamental firm price after a $1 \%$ change in the voting right. All significant estimates of $\pi$ are negative. Firms with positive estimates of $\pi$ include Petrobras (state-owned oil giant), Vale (whose preferred shareholders may also vote in General Assembly Deliberations), Ambev and Santander (both part of global corporations).

The results indicate that increases in the price of the voting right decrease public cash flows. This happens because of the negative effect on the fundamental value of the firm. A low value of voting rights is a signal of low expropriation and private benefits. This supports the findings that companies with stronger shareholder rights present higher firm value and higher profits (Gompers et al., 2003) and that strong corporate governance is associated with higher operating performance (Klapper \& Love, 2004). Additionally, Dyck and Zingales (2004) find that Brazil is the country with the highest value for corporate control across 39 countries. They attribute this higher premium to lower investor protection and higher willingness to extract private benefits, which help explain the negative $\pi$ estimates. This is the main reason why B3's New Market (Novo Mercado, characterized by the highest level of corporate governance) does not allow companies to issue shares without voting rights, avoiding asymmetry in cash flows and voting rights. 
TABLE 1 Parameter estimation

\begin{tabular}{|c|c|c|}
\hline & $\pi$ & $\kappa$ \\
\hline Bradesco & $\begin{array}{c}-0.38^{* *} \\
(-0.77,-0.19)\end{array}$ & $\begin{array}{c}-0.07^{* *} \\
(-0.13,-0.05)\end{array}$ \\
\hline Ambev & $\begin{array}{c}-0.11^{* *} \\
(-0.51,-0.09)\end{array}$ & $\begin{array}{c}-0.07^{* *} \\
(-0.13,-0.02)\end{array}$ \\
\hline Braskem & $\begin{array}{c}-0.34^{* *} \\
(-0.49,-0.23)\end{array}$ & $\begin{array}{c}-0.21^{* *} \\
(-0.28,-0.14)\end{array}$ \\
\hline CBD & $\begin{array}{c}-0.37^{* *} \\
(-0.93,-0.19)\end{array}$ & $\begin{array}{c}-0.65^{* *} \\
(-0.91,-0.51)\end{array}$ \\
\hline Cemig & $\begin{array}{c}-0.32^{* *} \\
(-0.63,-0.22)\end{array}$ & $\begin{array}{c}-0.11^{* *} \\
(-0.16,-0.06)\end{array}$ \\
\hline Itau & $\begin{array}{c}-0.70^{* *} \\
(-0.98,-0.48)\end{array}$ & $\begin{array}{c}-0.12^{* *} \\
(-0.21,-0.11)\end{array}$ \\
\hline Telefonica & $\begin{array}{c}-0.41^{* *} \\
(-0.49,-0.21)\end{array}$ & $\begin{array}{c}-0.17^{* *} \\
(-0.27,-0.12)\end{array}$ \\
\hline Copel & $\begin{array}{c}-0.17^{*} \\
(-0.30,0.01)\end{array}$ & $\begin{array}{c}-0.48 \\
(-0.70,0.16)\end{array}$ \\
\hline Eletrobras & $\begin{array}{c}-0.15^{*} \\
(-0.37,0.01)\end{array}$ & $\begin{array}{c}-0.06^{* *} \\
(-0.13,-0.01)\end{array}$ \\
\hline Oi & $\begin{array}{c}-0.15 \\
(-0.56,0.23)\end{array}$ & $\begin{array}{c}-0.07^{*} \\
(-0.29,0.03)\end{array}$ \\
\hline Tim & $\begin{array}{c}-0.15 \\
(-0.20,0.11)\end{array}$ & $\begin{array}{c}-0.10 \\
(-0.15,0.05)\end{array}$ \\
\hline Vale & $\begin{array}{c}0.76^{* *} \\
(0.27,1.03)\end{array}$ & $\begin{array}{c}-0.02 \\
(-0.03,0.01)\end{array}$ \\
\hline Petrobras & $\begin{array}{c}0.46 \\
(-0.08,0.71)\end{array}$ & $\begin{array}{c}-0.01 \\
(-0.04,0.00)\end{array}$ \\
\hline Santander & $\begin{array}{c}0.19 \\
(-0.28,0.72)\end{array}$ & $\begin{array}{c}0.02 \\
(-0.04,0.05)\end{array}$ \\
\hline
\end{tabular}

Note: We report estimates of $\pi$ and $\kappa .^{* *}$ and ${ }^{*}$ denote statistical significance at the $5 \%$ and $10 \%$ levels, respectively. We report the $2.5 \%$ and $97.5 \%$ empirical percentiles (inside brackets) computed with the parametric bootstrap (see Lutkepohl, 2007, p. 709).

There is a previous finding in the literature that provide insights about our results. Dyck and Zingales (2004) find Brazil is the country (among 39 countries) with the highest value for corporate control. They relate their results of a higher premium to lower investor protection and higher willingness to extract private benefits. The lower investor protection would explain the significantly negative $\pi$ estimates.

Altogether, there is evidence that an increase in the value of voting rights for Brazilian firms generates a negative effect on firms' cash flows. We claim that this is because common shareholders can extract more private benefits and, hence, generate a decrease in public cash flows. A second finding relates good (bad) news for firms' cash flows with a decrease (increase) in the common-preferred premium.

\section{4 | CONCLUSION}

We present a framework to study dual-class shares in which both public and private cash flows affect share prices. We disentangle the effects of both types of cash flows using a CVAR approach in order to determine how private benefits affect the fundamental share price, and hence equity-holders' wealth. We find that an increase in the value of voting rights negatively affects firm value by decreasing public cash flows. This finding is in line with the literature on agency and entrenchment problems that advocates the one-share-one-vote rule (Adams \& Ferreira, 2008). Our empirical analysis reveals a negative relation between voting right and firm value, justifying to some extent the Novo Mercado segment of the Brazilian Stock Exchange, which does not allow firms to issue shares without voting rights. 


\section{ENDNOTES}

${ }^{1}$ See Appendix for the details on how to obtain the elements of $\Phi$.

${ }^{2}$ For instance, Nenova (2001) examines private benefits for Brazilian firms.

${ }^{3}$ Law number 10.303 of 31 October 2001, see http://www.cvm.gov.br/port/atos/leis/lei10303.asp and http://www. planalto.gov.br/ccivil_03/leis/l6404consol.htm.

${ }^{4}$ The estimation uses the full information maximum likelihood framework of Johansen (1991). We determine the lag length by taking the most parsimonious specification without residual autocorrelation. See details in Appendix.

\section{REFERENCES}

Adams, R., \& Ferreira, D. (2008). One share, one vote: The empirical evidence. Review of Finance, 12, 51-91.

Bigelli, M., \& Croci, E. (2013). Dividend privileges and the value of voting rights: Evidence from Italy. Journal of Empirical Finance, 24, 94-107.

Burkart, M., \& Lee, S. (2008). One share - One vote: The theory. Review of Finance, 12, 1-49.

Coles, J. L., Lemmon, M. L., \& Meschke, J. (2012). Structural models and endogeneity in corporate finance: The link between managerial ownership and corporate performance. Journal of Financial Economics, 103, 149-168.

Doidge, C. (2004). U.S. cross listing and the private benefit of control: Evidence from dual-class firms. Journal of Financial Economics, 72, 519-553.

Dyck, A., \& Zingales, L. (2004). Private benefits of control: An international comparison. Journal of Finance, 59, $537-600$.

Fernandes, M., \& Novaes, W. (2019). The government as a large shareholder: Impact on corporate governance. Technical report, Sao Paulo School of Economics, FGV and PUC-Rio.

Gompers, P., Ishii, J., \& Metrick, A. (2003). Corporate governance and equity prices. Quarterly Journal of Economics, 118, 107-156.

Gompers, P. A., Ishii, J., \& Metrick, A. (2009). Extreme governance: An analysis of dual-class firms in the United States. The Review of Financial Studies, 23, 1051-1088.

Gonzalo, J., \& Ng, S. (2001). A systematic framework for analyzing the dynamic effects of permanent and transitory shocks. Journal of Economics Dynamics and Control, 25, 1527-1546.

Grossman, S. J., \& Hart, O. D. (1988). One share-one vote and the market for corporate control. Journal of Financial Economics, 20, 175-202.

Himmelberg, C. P., Hubbard, R. G., \& Palia, D. (1999). Understanding the determinants of managerial ownership and the link between ownership and performance. Journal of Financial Economics, 53, 353-384.

Johansen, S. (1991). Estimation and hypothesis testing of cointegration vectors in Gaussian vector autoregressive models. Econometrica, 59, 1551-1580.

Khanna, T., \& Yafeh, Y. (2007). Business groups in emerging markets: Paragons or parasites? Journal of Economic Literature, 45, 331-372.

Klapper, L., \& Love, I. (2004). Corporate governance, investor protection, and performance in emerging markets. Journal of Corporate Finance, 10, 703-728.

Lutkepohl, H. (2007). New introduction to multiple time series analysis, Berlin, Heidelberg: . Springer.

Nenova, T. (2001). Control values and changes in corporate law in Brazil. Technical report, The World Bank.

Yan, B., \& Zivot, E. (2010). A structural analysis of price discovery measures. Journal of Financial Markets, 13, 1-19.

Zingales, L. (1994). The value of the voting right: A study of the milan stock exchange experience. Review of Financial Studies, 7, 125-148.

Zingales, L. (1995). What determines the value of corporate votes? Quarterly Journal of Economics, 110, 1047-1073.

\section{SUPPORTING INFORMATION}

Additional supporting information may be found online in the Supporting Information section at the end of this article.

How to cite this article: Scherrer CM, Fernandes M. The effect of voting rights on firm value. International Review of Finance. 2020;1-6. https://doi.org/10.1111/irfi.12318 